\title{
Macro-Economic Determinants of High Technology Exports
}

\author{
Monika Gaur, Ravi Kant, and N. M. P. Verma
}

\begin{abstract}
An evaluation of the outcome of research and development is intrinsic for building a long-term foundation for economic development. The high technology exports are one indicator that can access the outcome of research and development of the economy. This study employed the data of high tech exports of 15 developed and developing economies during 2007-2018. The fixed effect regression estimates were analysed upon, validation of which is enumerated by the Hausman test. Two significant findings that the study implicates are, first, the benefits of an outward-oriented policy that has fewer tariff burdens will result in the promotion of high-tech exports. Secondly, the study is intrigued by the role of financial market development, which in turn is exportoriented, thereby reducing the foreign exchange burden. The enhanced access to financial markets and increased depth has proven to be congenial for high tech exports.
\end{abstract}

Index Terms - Research and Development; Developed Economies; Investment; High Tech, Export.

\section{INTRODUCTION}

The imperative of Research and Development (R\&D) is now well recognized by developmental economists and policymakers across the globe. The work Romer and Lucas on endogenous growth theory appeared, which concentrated on the role of innovation on economic growth and development [1], [2]. According to Todaro and Smith [3], capital accumulation, growth in population, and technological progress are three significant determinants of economic growth. It is well recognized among economists, policy analysts and researchers, that two factors, labor in the form of human resources and capital in the form of technological change, are prominent in respect to expand economic growth, development, and well-being. The landmark work of Schultz on human capital showed the importance of human resources in economic growth [4]. On the other hand, some recent economic growth theories have emphasized the relevance of technological change on economic growth and development. The theories and models supported the perspective of innovation/R\&D as the key driver for economic growth and development. Most of the studies evaluated the extent the contribution of innovation from the channels of investments, Foreign Direct Investment (FDI) inflow, Gross Domestic Product (GDP) growth, and Gross Capital Formation (GCF). only after the work of Robert Solow. Empirically, a small number of the technological progress as an exogenous factor is considered

Published on September 18, 2020

Monika Gaur, University of Delhi, India.

(e-mail: mgaur177@gmail.com)

Ravi Knat, Shri Ram College of Commerce, University of Delhi, India. (corresponding e-mail: ravi.kant ${ }^{@}$ srcc.du.ac.in)

N. M. P. Verma, School of Economics and Commerce, BBAU, India.

(e-mail: nmpverma@ ${ }^{@}$ gmail.com) economies have developed new technologies, while many other countries have adopted the new technologies via trade, adaptation, and foreign direct investment [5], [6]. Further, it recognized the relevance of technological change, innovation, and R\&D on economic growth and development. It plays a crucial role as a factor of productivity, competitiveness, and real investments in the economy. A number of studies have evaluated the R\&D pattern and accessed the R\&D investment and its efficiency at a firm level [7], [8] vis a vis growth of productivity at the domestic level [9]-[11]. The endogenous technological change has been widely recognized through the channels of education and human resource management as a significant factor in long-term growth. The number of works such as [12]-[18] are concentrated on the role and importance of investment in $\mathrm{R} \& \mathrm{D}$ on economic progress.

The importance of specialization in technological progress and export of high technology products on economic growth has now been well established in the literature of international trade. Availability of extensive literature in the area of productivity growth and technology, which displays the picture that productivity growth can create the differences in technological opportunities in the economy [19]-[22]. It has been viewed that there is a flourishing interest in high technology trade in the world due to the high possibility of gains from trade. It can also create some positive externalities in the economy through rising competition and creating an environment for innovation and R\&D. Further, some studies also displayed the fact that industries that are involved in the production of high technology products are the fastest growing industries in the world. These industries are helpful in increasing productivity in other complementary industries through its positive externalities and dynamism.

The presented study empirically examines the determinants of Research and Development. Outcomes are measured on the basis of high technology exports at the global level. The significant factors that are well considered as a determinant of the high technology exports are R\&D investment, unemployment rate, GCF, Net FDI inflow, and Governmental expenditure on education. The sensitivity and robustness effects of the GDP growth rate, $R \& D$ investments, and other indices are evaluated by using the data of 15 developed and developing economies for the period 2007 to 2018 . The next section of the presented paper reflects the literature related to the determinants of $R \& D$, methodology, and analysis. Further, it shows the results and their interpretation. The last segment provides the conclusion and policy implications. 


\section{LITERATURE REVIEW}

After the 1960s, extensive research has been carried out in the field of trade and economic growth. The export growth has played a pivotal role in expanding economic growth in many countries. The growth in the export is correlated with productivity and hence GDP growth [23]. The volume and value of merchandise and services determine the benefits of export-oriented growth. In the recent era, the researchers began to realize the correlation between innovation or R\&D, high-tech exports, and economic growth. They largely emphasized on high technology trade [24]. Research on OECD countries carried out by Braunerhjelm and Thulin demonstrates that the R\&D investments are a primal determinant to explain the high tech exports [25]. In another study that demonstrates some other relevant important determinants of high tech exports other than R\&D investments, which are represented as technological capabilities, the number of patents, Gross Enrolment Ratio (GER) in higher education all have direct effects on high technology exports [26]. Literature in the domain of productivity, economic growth, and development models are mostly concentrated on the role of $R \& D$, innovation, and technology change and their impact on economic progress. On the other hand, there are some studies which have been focused on the determinants and factors of R\&D on the growth of productivity at the micro and macro level. Micro-level studies are related to increasing returns to scale specific to increase the gains from innovation and research dissemination. At the macro level, there are numerous factors that influenced the $R \& D$ outcomes such as investment, GCF, GDP growth, FDI inflow, government expenditure on education. For instance, some of the empirical studies in respect of technological change, innovation, and domestic $R \& D$ have been considered as an important factor of real per capita GDP [27]-[29]. Verma and Srivastava have found the positive role of innovation in irrigation [30]. Further, Verma and Singh have seen the software exports rising in India [31]. For more observation [32], [33]. On the other hand, Matsushima et al. established a model through which they showed how exports and imports affected the innovation strategies of the firms [34]. According to them, trade openness influences the innovation strategies and R\&D activities of the firms. In a study by Pottelsberghe et al. by using panel data of 360 United States manufacture firms analyzed, the expenditure on $R \& D$ to exchange rate change from the period 1975 to 1987 [35]. They interpreted the results that firms in the industries with an average $R \& D$ spending, at least 3 percent of sales revenue, respond to an exchange rate increment with accumulated R\&D expenditures while firms in the industries with lower levels R\&D magnitude has not shown any increments. On the other hand, a study by Griffth and Reenen, evaluated the consequence of fiscal inducements on $R \& D$ investment. A study conducted of 9 Organisation for Economic Cooperation and Development (OECD) countries based on the econometric model of R\&D investment which analyzed the results by employing a panel data on the tax changes and R\&D spending over a 19 year period from 1979 to 1997 ; this study found that tax payments are effective in order to increase the R\&D level. Further, this study found that a reduction of 10 percent in the cost of $R \& D$ affects over a 1 percent increase in the R\&D level [36]. In order to identify the national level factors of $R \& D$ investment with a special concentration on the trade, investment, and economic growth through the channels of the role of patent rights security. Wang, investigated Extreme-Bounds-Analysis (EBA) trials on data from 26 OECD economies from the year 1996 to 2006 and accessed that the higher or tertiary education with the magnitude of scientific researches in a country were robust factors that reflected the favorable effects on R\&D magnitude [37]. The inflow of foreign technology had a robust and adverse effect on national $R \& D$, and the patent rights security and income growth rate have shown a weak determinant of R\&D investment. Several studies that focused on the determinants or factors of $R \& D$ investment and innovation in the economy, GDP growth, GDP per capita, trade, FDI, and fiscal policies of the government play a significant contribution to the technology transfers, innovation, and R\&D. A study by Schmookler, focused on the role of GDP growth rates on R\&D investments [38]. Further, Romer, showed that the markets imply stronger incentives to conduct $R \& D$, which in turn leads to faster growth [39]. As the purchasing power of consumers increases, they are inclined to distribute a bigger portion of their financial gain towards differentiated products, which are more R\&D-intensive [40]. It is well anticipated that the elasticity of $R \& D$ per capita with respect to GDP per capita should be high [41], [42]. Arguments exist both in favor of and against the openness of trade and their spillover impact on innovation and technological change to protect industries from the global competition [43]. Some studies show such as [44]-[47] that innovation reduces with the competition. Nevertheless, on the other hand, some studies by Nickell and Blundell et al. observed that this is not consistent [48], [49]. Some studies found that in most developing and OECD countries, the government provides R\&D subsidizations to the universities and research institutes in the assistance of fundamental research [50]. It is thus expected that the budget of the authorities is very probable to impact the domestic R\&D investments, and it is also noticed that in developing countries, the government also executes the responsibility of piquant in Research and Development directly [51]. Pratinidhi and Verma have studied short and long-run causality on inflation, export, and lending rate. This study has observed good relations in lending rates and exports [52].

It has been well recognized that besides the GDP growth, investments, FDI, and trade, the policies of the government related to fiscal policy, when the government provides grants to universities and research institutes, it affects the $\mathrm{R} \& \mathrm{D}$ scenario in the economy.

\section{DATA, METhodology, AND ANALYSIS}

The study employed 15 developed and developing countries. The countries are Switzerland, Netherlands, Sweden, United Kingdom, Singapore, Finland, Denmark, Germany, Iceland, Malaysia, Bulgaria, Croatia, Thailand, Russia Federation, Romania. The time period of the data set is 2007-2018 from the source of the World Bank database, and the variables of the study are tabulated in annexure 1. 
High-tech exports $=f(R \& D$ exp. \% GDP, GCF \% of GDP, Financial Institutions Access Index (FIAI), Financial

Markets Depth Index (FMDI), Tariff rate, Information and Communication Technology (ICT) goods export, GDP per capita, Real effective Exchange Rate (ER), Import Value

Index, Labor force with advanced Edcuation (female)

The above equation is estimated using the fixed effect since the fixed estimates were found to be efficient using the Hausman test.

TABLE 1: DESCRIPTION AND SOURCE OF VARIABLES

\begin{tabular}{|c|c|}
\hline Name & Description \\
\hline $\begin{array}{l}\text { High-technology } \\
\text { exports (\% of } \\
\text { manufactured exports) }\end{array}$ & $\begin{array}{l}\text { Products with high R\&D intensity, such as in } \\
\text { aerospace, computers, pharmaceuticals, } \\
\text { scientific instruments, and electrical } \\
\text { machinery. }\end{array}$ \\
\hline $\begin{array}{l}\text { R\&D expenditure (\% } \\
\text { of GDP) }\end{array}$ & $\begin{array}{l}\text { "Research and Development expenditure as a } \\
\text { percent of GDP. This include both capital and } \\
\text { current expenditures in the four main sectors: } \\
\text { Business enterprise, Government, Higher } \\
\text { education and Private non-profit. R\&D covers } \\
\text { basic research, applied research, and } \\
\text { experimental development." }\end{array}$ \\
\hline FIAI(Access index) & Financial Institutions Access Index \\
\hline FMDI(depth index) & Financial Markets Depth Index \\
\hline $\begin{array}{lr}\begin{array}{l}\text { Tariff rate, } \\
\text { favored }\end{array} & \text { most } \\
\text { weighted } & \text { mean, } \\
\text { manufactured } & \\
\text { products }(\%) & \end{array}$ & $\begin{array}{l}\text { It is the average of most favored nation rates } \\
\text { weighted by the product import shares } \\
\text { corresponding to each partner country. } \\
\text { Manufactured products are commodities } \\
\text { classified in Standard International Trade } \\
\text { Classification (SITC) revision } 3 \text { sections 5-8 } \\
\text { excluding division } 68 \text {. }\end{array}$ \\
\hline $\begin{array}{l}\text { ICT goods exports (\% } \\
\text { of total goods exports) }\end{array}$ & $\begin{array}{l}\text { It includes computers and peripheral } \\
\text { equipment, communication equipment, } \\
\text { consumer electronic equipment, electronic } \\
\text { components, and other information and } \\
\text { technology goods (miscellaneous). }\end{array}$ \\
\hline $\begin{array}{l}\text { GDP per capita } \\
\text { (constant } 2010 \text { US\$) }\end{array}$ & $\begin{array}{l}\text { "GDP per capita is gross domestic product } \\
\text { divided by midyear population. GDP is the } \\
\text { sum of gross value added by all resident } \\
\text { producers in the economy plus any product } \\
\text { taxes and minus any subsidies not included in } \\
\text { the value of the products. It is calculated } \\
\text { without making deductions for depreciation of } \\
\text { fabricated assets or for depletion and } \\
\text { degradation of natural resources. Data are in } \\
\text { constant } 2010 \text { U.S. dollars." }\end{array}$ \\
\hline $\begin{array}{l}\text { Real effective } \\
\text { exchange rate index } \\
(2010=100)\end{array}$ & $\begin{array}{l}\text { "It is the nominal effective exchange rate (a } \\
\text { measure of the value of a currency against a } \\
\text { weighted average of several foreign } \\
\text { currencies) divided by a price deflator or } \\
\text { index of costs." }\end{array}$ \\
\hline $\begin{array}{l}\text { Import value index } \\
(2000=100)\end{array}$ & $\begin{array}{l}\text { It denotes the current value of imports value } \\
\text { indexes are current value of imports (c.i.f.) } \\
\text { converted to U.S. dollars and expressed as a } \\
\text { percentage of the average for the base period } \\
(2000) \text {. }\end{array}$ \\
\hline $\begin{array}{l}\text { Labor force with } \\
\text { advanced education, } \\
\text { female (\% of female } \\
\text { working-age } \\
\text { population with } \\
\text { advanced education) }\end{array}$ & $\begin{array}{l}\text { "Advanced education comprises short-cycle } \\
\text { tertiary education, a bachelor's degree or } \\
\text { equivalent education level, a master's degree } \\
\text { or equivalent education level, or doctoral } \\
\text { degree or equivalent education level according } \\
\text { to the International Standard Classification of } \\
\text { Education } 2011 \text { (ISCED, 2011)." }\end{array}$ \\
\hline
\end{tabular}

\section{RESULTS AND INTERPRETATION}

The study engulfs around the impact of various determinants while assessing high tech exports, which are thoroughly research-intensive. The descriptive statistics advise that the mean value of high tech exports is $19.26 \%$ of manufactured exports with large deviations subsuming to 11.38. Notably, the average gross expenditure on research and development is at most $1.8 \%$ of GDP in the said nations, along with a maximum value of $3.7 \%$ of GDP (Table 2 ).

\begin{tabular}{|c|c|c|c|c|c|}
\hline Variable & $\begin{array}{c}\mathrm{Ob} \\
\mathrm{s}\end{array}$ & Mean & $\begin{array}{l}\text { Std. } \\
\text { Dev. }\end{array}$ & Min & Max \\
\hline $\begin{array}{l}\text { High-tech } \\
\text { exports (\% of } \\
\text { manufactured } \\
\text { exports) }\end{array}$ & 143 & 19.264 & 11.381 & 4.413 & 60.714 \\
\hline $\begin{array}{l}\text { R\&D exp. } \% \\
\text { GDP }\end{array}$ & 143 & 1.831 & 1.109 & .201 & 3.749 \\
\hline GCF $\%$ of GDP & 143 & 22.503 & 3.922 & 13.904 & 36.974 \\
\hline $\begin{array}{l}\text { FIAI(Access } \\
\text { index) }\end{array}$ & 143 & .674 & .218 & .165 & .987 \\
\hline $\begin{array}{l}\text { FMDI(depth } \\
\text { index) }\end{array}$ & 143 & .597 & .311 & .033 & .995 \\
\hline Tariff rate & 127 & 3.649 & 1.345 & 1.72 & 9.17 \\
\hline $\begin{array}{l}\text { ICT goods } \\
\text { export }\end{array}$ & 142 & 6.626 & 8.442 & .068 & 39.35 \\
\hline GDP per capita & 143 & $\begin{array}{c}32567.4 \\
2\end{array}$ & $\begin{array}{c}23081.7 \\
8\end{array}$ & $\begin{array}{c}4744.75 \\
7\end{array}$ & $\begin{array}{c}77451.9 \\
8\end{array}$ \\
\hline $\begin{array}{l}\text { Real effective } \\
\text { ER }\end{array}$ & 132 & 100.862 & 9.227 & 79.251 & 153.608 \\
\hline $\begin{array}{l}\text { Import Value } \\
\text { Index }\end{array}$ & 142 & 305.268 & 146.285 & 139.199 & 760.708 \\
\hline $\begin{array}{l}\text { Labor force with } \\
\text { advanced } \\
\text { education(female } \\
\text { ) }\end{array}$ & 132 & 77.772 & 6.498 & 60.932 & 90.608 \\
\hline
\end{tabular}

The study further turns to the regression analysis where Research and Development expenditure as a \% GDP positively and significantly promotes high tech exports (table 1.3). The results are in congruence with the fact that high tech exports are concerned with high demand for research and development, the upshot of which suggests that economies aspiring to cater to high exports exhaustively invest in research and development activities. Concomitant to the above results, the gross capital formations have also escalated high tech exports (table 1.3), apparently due to easy access to infrastructural facilities such as roads, schools, and drains. Such investments have both push and pull impacts through incentivizing and facilitating the high tech export-oriented production.

\section{A. Financial Role}

The research suggests that financial development has significantly enhanced high tech exports (Table 3), noticeably due to the fact that such development has facilitated high tech exports and has been proven to be providing desired benefits by reducing financial cost and easy availability of finance. The financial development is accounted for by two indices, namely, FIAI and FMDI, to track their impact in a lucid manner. The access to financial institutions such as banks acts as financial infrastructure facilitators, and they enhance the availability of credit to the 
exporters. Further, the study dissects over the impact of the depth of financial markets and iterates that deep financial markets escalate high-tech exports. The results suggest that a unit change(increase) in FIAI culminates to 29.09 units increase in high tech exports; also, a unit increase in FMDI approximates to 24.29 unit increases in exports of high tech goods, which is even statistically significant at $1 \%$ (Table 3 ).

TABLE 3: REGRESSION RESULTS

\begin{tabular}{|c|c|c|c|c|c|c|c|c|c|c|c|}
\hline & $(1)$ & $(2)$ & (3) & (4) & $(5)$ & $(6)$ & $(7)$ & $(8)$ & $(9)$ & (10) & (11) \\
\hline \multirow[t]{2}{*}{$\begin{array}{l}\mathrm{R} \text { and } \mathrm{D} \\
\text { exp. \% GDP }\end{array}$} & $6.327 * * *$ & $6.814 * * *$ & $5.640 * * *$ & $5.222 * * *$ & $7.933 * * *$ & $7.561 * * *$ & $7.002 * * *$ & $7.522 * * *$ & $7.819 * * *$ & $9.273 * * *$ & $\begin{array}{l}9.273 * * \\
*\end{array}$ \\
\hline & (1.804) & (1.719) & (1.683) & (1.660) & $(1.730)$ & (1.643) & (1.686) & (1.508) & $(1.473)$ & (1.292) & $(1.292)$ \\
\hline \multirow{2}{*}{$\begin{array}{l}\text { GCF \% of } \\
\text { GDP }\end{array}$} & & $0.446 * * *$ & $0.476^{* * *}$ & $0.423 * * *$ & $0.375 * * *$ & $0.352 * * *$ & $0.298 * * *$ & 0.165 & $0.235^{* *}$ & $0.384 * * *$ & $\begin{array}{l}0.384 * * \\
*\end{array}$ \\
\hline & & $(0.116)$ & $(0.112)$ & $(0.112)$ & $(0.110)$ & $(0.104)$ & $(0.111)$ & $(0.111)$ & $(0.111)$ & $(0.104)$ & $(0.104)$ \\
\hline \multirow[t]{2}{*}{$\begin{array}{l}\text { FIAI(Access } \\
\text { index) }\end{array}$} & & & $17.623 * * *$ & $16.893 * * *$ & $15.872 * * *$ & $15.103 * * *$ & $15.173 * * *$ & $24.595 * * *$ & $28.177 * * *$ & $29.099 * * *$ & $\begin{array}{l}29.099 * \\
* *\end{array}$ \\
\hline & & & $(5.059)$ & $(4.972)$ & $(5.082)$ & (4.819) & $(4.800)$ & $(5.294)$ & $(5.342)$ & $(5.062)$ & $(5.062)$ \\
\hline $\begin{array}{l}\text { FMDI(depth } \\
\text { index) }\end{array}$ & & & & $10.226 * *$ & $17.275 * * *$ & $18.002 * * *$ & $18.445^{* * *}$ & $25.066^{* * * *}$ & $21.018 * * *$ & $24.296 * * *$ & $\begin{array}{l}24.296^{*} \\
* *\end{array}$ \\
\hline Tariff rate & & & & (4.186) & $\begin{array}{l}(4.381) \\
-2.007 * * * \\
(0.734)\end{array}$ & $\begin{array}{l}(4.155) \\
-1.764^{* *} \\
(0.699)\end{array}$ & $\begin{array}{l}(4.151) \\
-1.703 * * \\
(0.697)\end{array}$ & $\begin{array}{l}(4.022) \\
-1.046 \\
(0.685)\end{array}$ & $\begin{array}{l}(4.226) \\
-0.426 \\
(0.710)\end{array}$ & $\begin{array}{l}(4.057) \\
-1.266 \\
(0.849)\end{array}$ & $\begin{array}{l}(4.057) \\
-1.266 \\
(0.849)\end{array}$ \\
\hline \multirow[t]{2}{*}{$\begin{array}{l}\text { ICT goods } \\
\text { export }\end{array}$} & & & & & & $0.543 * * *$ & $0.539 * * *$ & $0.326^{* *}$ & $0.248^{*}$ & $0.534 * * *$ & $\begin{array}{l}0.534 * * \\
*\end{array}$ \\
\hline & & & & & & $(0.148)$ & $(0.148)$ & $(0.137)$ & $(0.137)$ & $(0.159)$ & $(0.159)$ \\
\hline \multirow[t]{2}{*}{$\begin{array}{l}\text { GDP per } \\
\text { capita }\end{array}$} & & & & & & & 0.000 & $0.000 * *$ & $0.001 * *$ & $0.001 * * *$ & $\begin{array}{l}0.001 * * \\
*\end{array}$ \\
\hline & & & & & & & $(0.000)$ & $(0.000)$ & $(0.000)$ & $(0.000)$ & $(0.000)$ \\
\hline \multirow{2}{*}{$\begin{array}{l}\text { Real } \\
\text { effective ER }\end{array}$} & & & & & & & & $0.085^{*}$ & $0.123 * *$ & $0.104 * *$ & $0.104 * *$ \\
\hline & & & & & & & & $(0.047)$ & $(0.048)$ & $(0.041)$ & $(0.041)$ \\
\hline \multirow[t]{2}{*}{$\begin{array}{l}\text { Import } \\
\text { Value Index }\end{array}$} & & & & & & & & & $-0.017 * *$ & $-0.019 * * *$ & $\begin{array}{l}- \\
0.019 * * \\
*\end{array}$ \\
\hline & & & & & & & & & $(0.007)$ & $(0.006)$ & $(0.006)$ \\
\hline $\begin{array}{l}\text { Labor force } \\
\text { with }\end{array}$ & & & & & & & & & & $-1.002 * * *$ & $\begin{array}{l}- \\
1.002 * * \\
*\end{array}$ \\
\hline $\begin{array}{l}\text { advanced } \\
\text { education(fe } \\
\text { male) }\end{array}$ & & & & & & & & & & $(0.218)$ & $(0.218)$ \\
\hline _cons & $\begin{array}{l}7.679 * * \\
(3.321)\end{array}$ & $\begin{array}{l}-3.254 \\
(4.246)\end{array}$ & $\begin{array}{l}- \\
13.652 * * * \\
(5.049)\end{array}$ & $\begin{array}{l}- \\
17.301 * * * \\
(5.174)\end{array}$ & $\begin{array}{l}- \\
17.673 * * * \\
(5.789)\end{array}$ & $\begin{array}{l}- \\
20.758 * * * \\
(5.549)\end{array}$ & $\begin{array}{l}- \\
30.980 * * * \\
(9.280)\end{array}$ & $\begin{array}{l}- \\
55.381 * * * \\
(9.452)\end{array}$ & $\begin{array}{l}- \\
62.768 * * * \\
(9.647)\end{array}$ & $\begin{array}{l}7.589 \\
(19.094)\end{array}$ & $\begin{array}{l}7.589 \\
(19.094)\end{array}$ \\
\hline Obs. & 143 & 143 & 143 & 143 & 127 & 127 & 127 & 119 & 119 & 112 & 112 \\
\hline R-squared & 0.087 & 0.182 & 0.253 & 0.287 & 0.414 & 0.479 & 0.488 & 0.622 & 0.645 & 0.771 & 0.771 \\
\hline
\end{tabular}

Note: Standard errors are in parenthesis

$(* * * \mathrm{p}<0.01, * * \mathrm{p}<0.05, * \mathrm{p}<0.1)$

Source: Calculated by researchers by using STATA. Data compiled from the World Bank database, 2020. Link accessed:

https://data.worldbank.org/indicator

\section{B. Role of tariffs and exchange rate}

From here, it becomes crucial to determine the impact of tariffs as a proxy of restrictions imposed; tariffs negatively impact high tech exports making them more costly and hence uncompetitive, creating a dampening impact.

A unit increase in tariff creates a dampening effect of 1.26 units over high tech exports, which is highly significant at a $1 \%$ level of significance (Table 3 ).

Further, the exchange rate proxied by the real effective exchange rate is bound to enhance the high tech exports, making them relatively cheaper and hence more competitive. A unit increase in the real effective exchange rate enhances exports of high tech goods by 0.104 units (Table 3 ).

\section{GDP and high tech exports}

The research deduced that higher GDP per capita facilitates high tech exports, the contemporaneous benefits of GDP per capita lie with knowledge spillover across the borders that predominantly promotes research and development process. The coefficient of GDP per capita remains positive and statistically significant at $1 \%$ level of significance (Table 3). Further, the GDP per capita helps to build export capacity and enhances research and development.

\section{Labour force with advanced education}

Since high tech exports are research-driven, it becomes inevitable to study the labor force having advanced education; interestingly, the female labor force having advanced education had a negatively significant impact on high tech exports (Table 3). A unit increase in women labor force with advanced education leads to a 1 unit decrease in exports of high tech goods.

It is important that although the same coefficient for the male labor force was positive but statistically insignificant and hence is omitted from the model. Emphatically, here we can clearly see the emerging void between male and female skilled labor force.

From here, the role of the state is critically important to enhance access to advance education in general and to women in particular. 


\section{E. Robustness}

The above regression (Table 3 ) results are based upon fixed-effect model, we have employed the Hausman test in order to check the validity of the fixed effect, whose null hypothesis is that fixed and random effect is the same. The P-value of the Hausman test, which follows chi-square distribution, is 0 , which suggests a failure to accept the null hypothesis (Table 4).

\begin{tabular}{|c|c|}
\hline & Coef. \\
\hline $\begin{array}{l}\text { Chi-square test value } \\
\text { P-value }\end{array}$ & $\begin{array}{c}317.296 \\
0\end{array}$ \\
\hline
\end{tabular}

\section{CONCLUSION}

The study empirically tested the key determinants of high tech exports and deduced that expenditure on research and development is crucial for the promotion of high tech exports for the fact that the latter are research-intensive. Additionally, gross capital formation has positive reverberation while facilitating high tech exports through its role in eradicating infrastructural bottlenecks. The expenditure on research and development has significantly augmented the high tech exports and has proven to be a facilitator. Similarly, capital formation has escalated the high tech exports through its linkage effects, i.e., forward and backward linkages. Capital formation influences the production capacity and hence income through multiplier effects.

Further, the study is intrigued by the role of financial market development, which in turn is export-oriented, thereby reducing the foreign exchange burden. The enhanced access to financial markets and increased depth has proven to be congenial for high tech exports. The financial markets provide easy access to finance to the investors and hence supplements the output growth of export-oriented products, especially which are high tech.

Further, the study implies that the benefits of an outwardoriented policy with reduced tariff burdens that will result in the promotion of high-tech exports; tariffs negatively impact high tech exports, making them more costly and hence uncompetitive, creating a dampening impact. The outward regime s well proliferated by the World Trade Organisation, which has pioneered free and flexible trade across the globe.

For women's participation, a unit increase in women's labor force with advanced education leads to a 1 unit decrease in exports of high tech goods. It is imperative here that although the same coefficient for the male labor force was positive but statistically insignificant and hence is omitted from the model. Emphatically, here we can clearly see the emerging void between male and female skilled labor force. From here, the role of the state is critically important to enhance access to advance education in general and to women in particular.

The research deduced that higher GDP per capita facilitates high tech exports; the contemporaneous benefits of GDP per capita lie with knowledge spillover across the borders that predominantly promotes the research and development process. Further, the exchange rate proxied by the Real Effective Exchange Rate is bound to enhance the high tech exports, making them relatively cheaper and hence more competitive. A unit increase in the real effective exchange rate enhances exports of high tech goods by 0.104 units. The exchange rate regime is crucial since excessive depreciation, if unchecked, can create a problem for a nation; however, the reduced imports due to depreciation of currency strengthen the Balance of Payment (BOP) situation.

\section{POLICY IMPLICATIONS}

The study implicates the benefits of an outward-oriented policy with reduced tariff burdens that will result in the promotion of high-tech exports. Interestingly, the female labor force having advanced education had a negatively significant impact on high tech exports. From here, the role of the state is critically important to enhance access to advance education in general and to women in particular.

The study implies that the government should encourage advanced learning towards research pursuit. Also, economic growth should be well targeted to get desired outcomes in a befitting manner.
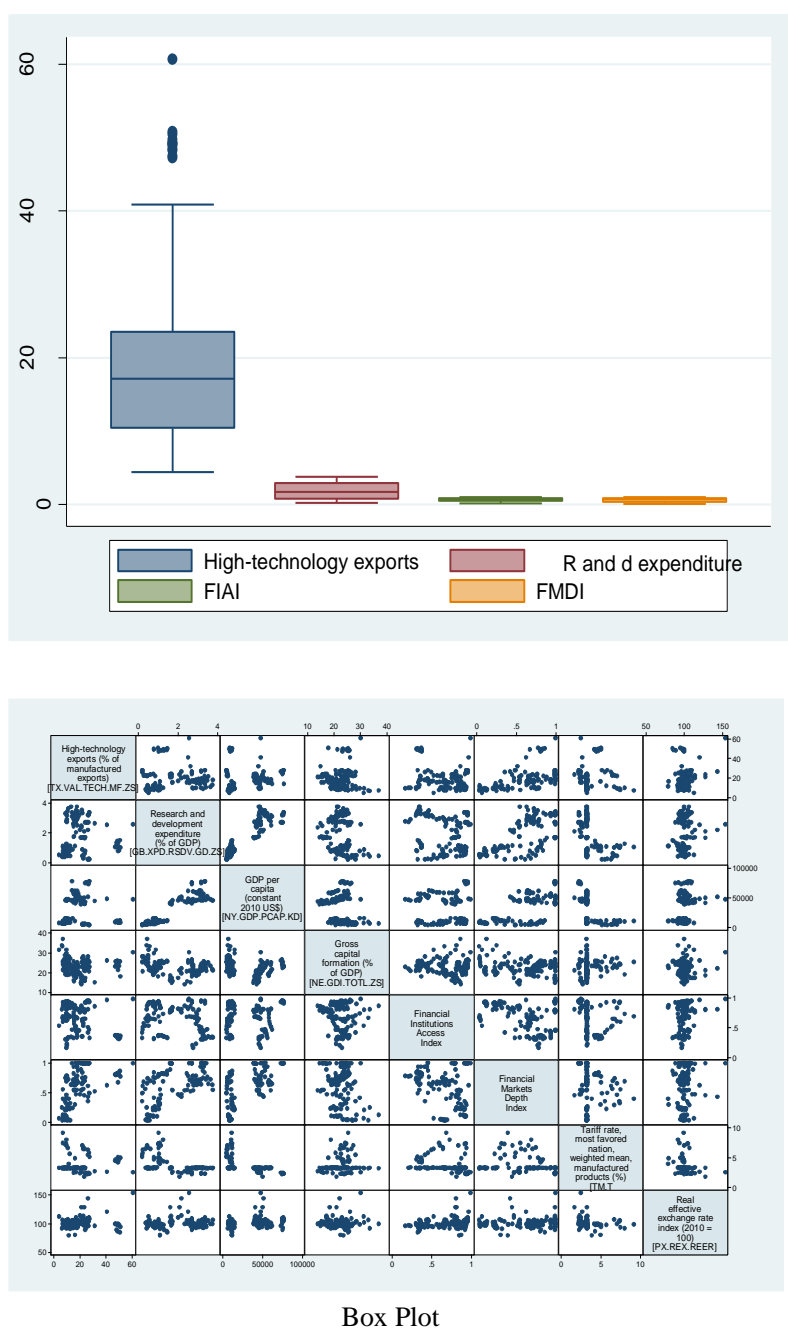


\section{REFERENCES}

[1] P M. Romer, "Endogenous Technological Change." Journal of Political Economy, 98(5), 71-102, 1990.

[2] R. Lucas, "Why Doesn't Capital Flow from Rich to Poor Countries?" American Economic Review, 80, pp.92-6, 1990.

[3] M. P. Todaro and S. C. Smith, "Economic Development (11th ed.) New York, Addison-Wesley, New York, 2012

[4] T. W. Schultz, "Investment in Human Capital". American Economic Review, 51(1): 1-17, 1961.

[5] D. Coe and A. Hoffmaister, "North-South R\&D Spillovers". Economic Journal, 107 (January), pp. 134-149., 1997.

[6] L. De Mello, "Foreign Direct Investment-led Growth: Evidence from Time Series and Panel Data, Oxford Economic Papers, 51(1), 133151. 1999.

[7] K. Wakelin, "Productivity Growth and R\&D Expenditure in UK Manufacturing Firms”. Research Policy, 30(7), 1079-1090, 2001

[8] P. Koellinger, "The Relationship Between Technology, Innovation, And Firm Performance: Empirical Evidence from E-business in Europe., Research Policy, 37(8), 1317-1328, 2008.

[9] M. Paasi," Efficiency of innovation systems in the transition countries", Economic Systems, 22 (3), 217-234, 1998.

[10] B. M Fraumeni and S. Okubo, "R\&D in the National Income and Product Accounts: A First look at its Effects on GDP. BEA Papers 0019. Bureau of Economic Analysis, 2002.

[11] M. Falk, "R\&D Spending in the High-tech Sector and Economic Growth". Research in Economics, 61, 140-47, 2007.

[12] Z. Griliches, "Returns to Research and Development Expenditures in the Private Sector. In New Developments in Productivity Measurement and Analysis" (J.W. Kendrick and B.N. Vaccara, eds.), Chicago University Press, pp. 419-462. Chicago, Ill: 1980a.

[13] E. Mansfield, "Industrial R\&D in Japan and the United States: A Comparative Study". American Economic Review, 78, 223-228, 1988.

[14] W. E. Cohen and D. A. Levinthal, "Innovation and Learning: The two faces of R\&D”, Economic Journal, 99(397), 569-596, 1989.

[15] B. Jovanovic and Y. Nyarko., "A Bayesian Learning Model Fitted to a Variety of Empirical Learning Curves, Brookings Papers on Economic Activity, Economic Studies Program, The Brooking Institution, 26, 247-305, 1995

[16] J. D. Adams and Z. Griliches, "Research Productivity in a System of Universities". NBER, Working Papers Series, No. 5833, 1996.

[17] G. G. Madden, S. J. Savage, and P. Bloxham, "Asian and OECD International R\&D spillover”. Applied Economics Letters 8, 431-435, 2001.

[18] W. Maloney and R. A. Clare, "Innovation Shortfalls". Review of Development Economics. Wiley Blackwell, 11(4). 665-684, 2007.

[19] J. Schumpeter, "The Theory of Economic Development." Cambridge (MA), Harvard University Press, 1934.

[20] R. R. Nelson and G. W. Winter, "An Evolutionary Theory of Economic Change”. Cambridge (MA), Harvard University Press, 1982.

[21] B. Verspagen, "Uneven Growth Between Interdependent Economies". Aldershot, Edward Elgar, 1993.

[22] J. Fagerberg, "Technology, Growth and Competitiveness, Selected Essays". Cheltenham, Edward Elgar, 2002.

[23] A. B. Bernard and J.B. Jensen, "Exporting and productivity in the USA", Oxford Review of Economic Policy, 20(3): 343-357, 2004.

[24] E. Tebaldi, "The Determinants of High-technology Exports: A Panel Data Analysis", Atlantic Economic Journal, 39(4): 343-353, 2011.

[25] P. Braunerhjelm and P. Thulin, "Can countries create Comparative Advantages? R\&D Expenditures, High-tech Exports and Country Size in 19 OECD Countries, 1981-1999”, International Economic Journal, 22(1): 95-111.

[26] M. Srholec, "High-tech Exports from Developing Countries: A Symptom of Technology Spurts or Statistical Illusion?," Review of World Economics/Weltwirtschaftliches Archiv, 143(2): 227-255, 2007.

[27] S. Teitel, "Patents, R\&D Expenditures, Country Size, And Per-capita Income: An International Comparison". Scientometrics. 29 (1), 137 159, 1994.

[28] J. C. Ginarte and W. G. Park, "Determinants of Patent Rights: A cross-national Study". Research policy, 26(3), 283-301, 1997.

[29] J. Mathews and Hu, Mei-Chih., "National Innovative Capacity in East Asia". Research Policy. 34. 1322-1349, 2005.

[30] N.M.P. Verma and A. Srivastava, "Economic Perspectives of Inclusive Innovation in Indian Irrigation", International Journal of Social Science and Development Policy, 2(1), 23-52, 2016.

[31] N.M.P. Verma, and S. D. Singh, "Employment, Export and Sustainability of Indian Software Industry". International Journal of
Social Science and Development Policy, 2, (2), 137-147, 2016.

[32] N. M. P. Verma, "Falling Employment and Growth Rates". Economy India, October, New Delhi, 10-11, 2017a.

[33] N. M. P. Verma, "Macroeconomic Instability in Indian Economy: A Contemporary Short Run Analysis". International Journal of Social Science and Development Policy, 3(2), 2017b.

[34] N. Matsushima, K. Yamamotor, "How Does Trade Openness Effect R\&D Activities?" Iser Seminar Series, 2008.

[35] B. Pottelsberghe and F. Lichtenber, "Does Foreign Direct Investment Transfer Technology Across Borders?. Review of Economics and Statistics. 83(3), 490-497, 2001.

[36] R. Griffth and J. V. Reenen, "Do R\&D Tax Credits Work? Evidence from a Panel of Countries 1979-1997”. Journal of Public Economics, 85(1), 1-31, 2002.

[37] E. C. Wang, "Determinants of R\&D Investment: The ExtremeBounds-Analysis approach applied to 26 OECD Countries". Research Policy, 39, 103-116., 2010.

[38] J. Schmookler, "Invention and Economic Growth". Harvard University Press, Cambridge, 1966.

[39] P. M. Romer, "The Origins of Endogenous Growth". Journal of Economic Perspectives. 8 (1): 3-22, 1994.

[40] J. R. Markusen, "Explaining the Volume of Trade: An Eclectic Approach". American Economic Review 76, 1002-1011, 1986.

[41] H. Braconier, "Do Higher per capita Incomes lead to more R\&D Expenditure". Review of Development Economics, 4(3), 244-257, 2000.

[42] J. L. Furman, M. E. Porter, and S. Stern, "The Determinants of National Innovation Capacity. Research Policy. 31, 899-933., 2002.

[43] J. C. Hallak and J. Levinsohn, "Fooling Ourselves: Evaluating the Globalisation and Growth Debate. Working Paper, 509, Research Seminar in International Economics, University of Michigan, 2003.

[44] K. J. Arrow, "Economic Welfare and the Allocation of Resources for Invention. In The Rate and Direction of Inventive Activity: Economic and Social Factors", Princeton University Press, pp. 609626., 1962.

[45] R. Gilbert, "D. M Newbury, "Preemptive Patenting and the Persistence of Monopoly". American Economic Review,72(3), 514526, 1982.

[46] G. M. Grossman and E. Helpman, "Innovation and Growth in the Global Economy", The MIT Press, London, England., 1991.

[47] P. Aghion and P. Howitt, "A Model of Growth through Creative Destruction”. Econometrica, 60(2), 323-351, 1992.

[48] S. J. Nickell, "Competition and Corporate Performance". Journal of Political Economy, University of Chicago press, 104(4), 724-746, 1996.

[49] R. Blundell, L. Deardon, C. Meghir, and S. Barbara, "Human Capital Investment: The Returns from Education and Training to the Individual, the Firm and the Economy", Fiscal Studies, Institute for fiscal studies, 20(1), 1-23, 1999.

[50] A. Geuna, "The Economics of Knowledge Production: Funding and the Structure of University Research”. Edward Elgar, Cheltenham, UK, 1999.

[51] R. N. Bebczuk, "R\&D Expenditures and the Role of Government around the World", Estudios de Economia, 29 (1), 109-121., 2002.

[52] Pratinidhi and N. M. P. Verma, "Short Run and Long Run Causality on Inflation, Export and the Lending Rate: An Empirical Study of India”. International Journal of Social Science and Development Policy. 4(1). 34-58, 2018 